\title{
Un puente sobre el abismo, de Higinio Noja Ruiz (1932). Cultura libertaria y literatura pacifista de entreguerras
}

\author{
Un puente sobre el abismo, by Higinio Noja Ruiz (1932). Libertarian \\ culture and interwar pacifist literature
}

\author{
Javier NAVARRO NAVARRO \\ Universitat de València*
}

\begin{abstract}
RESUMEN
El escritor, ensayista y militante anarquista Higinio Noja Ruiz publicó en 1932 la novela Un puente sobre el abismo en la Editorial Estudios de Valencia. En ella Noja abordó el tema de las guerras y la lucha contra ellas a través de su protagonista, Guillermo Arjona, un joven burgués mallorquín muy influido por su lectura de las novelas sobre la Primera Guerra Mundial y casi obsesionado con esta temática. Se analiza aquí en primer lugar la figura de Noja Ruiz (19941972), prolífico novelista social a la vez que ensayista y pensador libertario de las décadas de 1920 y 1930. La trayectoria de Noja es inseparable de la de la revista cultural y editorial libertaria valenciana Estudios (1928-1937), en la que Noja tuvo un muy importante rol y donde publicó numerosos artículos, libros y folletos. Estudios se caracterizó, entre otros temas, por su postura combativa en contra de la guerra y el militarismo, y a favor de la paz y el internacionalismo. Allí se difundieron ensayos y libros de esta temática, y también las más conocidas novelas del momento, muchas de carácter testimonial, que mostraban la vida en las trincheras o la retaguardia durante la Gran Guerra, a cargo de autores como Remarque, Barbusse, Glaeser, Renn, etc., y reseñadas por el propio Noja en sus páginas. Un puente sobre el abismo es en buena medida el resultado de todo ello.
\end{abstract}

PALABRAs ClAVE

Anarquismo; Pacifismo; Higinio Noja Ruiz, Estudios. Revista ecléctica; Literatura antibélica; Primera Guerra Mundial.

\section{ABstract}

In 1932, Higinio Noja Ruiz, writer and Spanish anarchist militant, published Un puente sobre el abismo (A Bridge over the Abyss, Valencia, Estudios). In this novel, Noja tackled the theme of wars and the struggle against them. Its protagonist is Guillermo Arjona, a young bourgeois Majorcan who is greatly influenced by novels about the First World War, with which he is rather obsessed. This article firstly analyses the figure of Noja Ruiz (1894-1972), a prolific social novelist, essayist and libertarian thinker in the 1920s and 1930s. Noja played a very important role in the libertarian cultural magazine Estudios (Valencia, 1928-1937) and its publishing house, with whom he published numerous articles, books and brochures. Estudios was characterised, among other things, by its combative stance against war and militarism, and its support of peace and internationalism. Estudios published and disseminated many essays and books on this subject, and many of the best-known novels of those years, which depicted life in the trenches or the rear-guard during the Great War, by authors such as Remarque, Barbusse, Glaeser, Renn, etc., were reviewed on its pages, mainly by Noja himself. A Bridge over the Abyss is to a large extent the result of this.

\section{KEYWORDS}

Anarchism; Pacifism; Higinio Noja Ruiz; Estudios. Revista Ecléctica; Anti-War Literature; World War I.

*. El autor pertenece al Grupo de Investigación de Excelencia Prometeo de la Generalitat Valenciana, GEHTID (Grup d'Estudis Històrics sobre les Transicions i la Democràcia, GVPROMETEO/2020/050) y al Grupo de Investigación GIUV2013-060 de la Universitat de València. 
Al menos me quedará la satisfacción de haber procurado tender en nuestra inquietante época un puente sobre el abismo que amenaza tragarnos a todos. Y eso, ya es algo que vale la pena.

Higinio NoJA RuIz, Un puente sobre el abismo (1932)

En este artículo se analizan tres planos estrechamente vinculados entre sí. Por un lado, la figura y obra del escritor y militante anarquista español Higinio Noja Ruiz (Nerva, Huelva, 1894-Valencia, 1972), escasamente conocidas todavía en la actualidad. Muy dinámico propagandista ácrata en los años del llamado Trienio bolchevique en Andalucía, Noja se convertiría posteriormente en un buen ejemplo del perfil del intelectual libertario cenetista autodidacta de las décadas de 1920 y 1930: maestro racionalista, literato, periodista, conferenciante, ideólogo y pensador social, etc. Sus novelas y cuentos publicados desde esos años, y también su producción ensayística y doctrinal, tuvieron una amplia acogida y una importante influencia en los medios obreros y específicamente libertarios hasta el final de la Guerra Civil.

El segundo ámbito tiene como eje Estudios. Revista Ecléctica, publicación anarquista de carácter cultural editada en Valencia entre 1928 y 1937 y sucesora a su vez de Generación Consciente, aparecida en Alcoi en 1923. Estudios se convirtió en abanderada y difusora de determinadas cuestiones afines a la sensibilidad libertaria del momento, en particular aspectos como la defensa del control de la natalidad, la eugenesia y la reforma sexual (por los que fue particularmente conocida), aunque también el naturismo o la medicina alternativa, y en general temas de divulgación cultural habituales en los medios obreristas de la época. Asimismo, Estudios tuvo en el antibelicismo y el pacifismo uno de sus principales ejes temáticos, y difundió en sus páginas y catálogos de librería muchos de los títulos de los escritores más representativos de la literatura antibelicista y pacifista internacional de entreguerras, en primer lugar la que se centraba en denunciar lo ocurrido en la Gran Guerra de 1914-1918 (con autores como Erich Maria Remarque, Romain Rolland, Henri Barbusse, Ludwig Renn, etc.), al tiempo que alertaba sobre la inminencia de una nueva conflagración mundial. Higinio Noja Ruiz fue precisamente director literario de Estudios, y responsable de su sección de "Bibliografía” durante gran parte de la vida de la publicación.

Por último, se analiza aquí Un puente sobre el abismo, novela escrita por el propio Noja Ruiz y publicada por la Editorial Estudios en 1932. Su protagonista es Guillermo, un joven burgués de la Mallorca de aquellos años, particularmente influido casi obsesionado- por la lectura de esa literatura de denuncia de los horrores de la Gran Guerra. Ello hace que se desarrolle en él una especial sensibilidad pacifista, lo que le lleva a comprometerse finalmente en la difusión publicística de esta literatura y en una activa pedagogía contra la guerra. Un puente sobre el abismo es un ejemplo de la recepción e interpretación de esa corriente literaria pacifista de entreguerras a la que antes aludíamos, por parte del propio Noja, así como una síntesis de las preocupaciones reflejadas en las páginas de la revista Estudios y en su catálogo de librería por aquellos años, y en general de la opinión de amplios sectores del movimiento libertario, sobre la cuestión.

\section{La figura de Higinio Noja Ruiz}

Higinio Noja fue autor de más de una treintena de libros o folletos (y casi otros tantos títulos inéditos), así como de innumerables artículos en periódicos y revistas entre 1910 y 1939. Las temáticas que abordó fueron extremadamente diversas: puede decirse que Noja Ruiz escribió sobre prácticamente todos los temas de interés para el público 
lector obrerista de las décadas de 1920 y 1930. Todo ello contrasta con el escaso conocimiento actual de su figura o la escasez de investigaciones monográficas en torno a su vida o su obra ${ }^{1}$.

Higinio Noja Ruiz nació en Nerva (Huelva) en 1894, junto a las minas de Riotinto. Su padre trabajaba como químico en la Riotinto Company Limited, donde también se empleó Noja en su adolescencia y primera juventud. Allí se despertó su conciencia de la explotación laboral y la desigualdad social, y en paralelo a su curiosidad intelectual (y un interés temprano por la pedagogía que le llevó a iniciar estudios de Magisterio) y a su voracidad lectora, empezó a escribir ya desde los 15 años artículos sobre la situación de las minas en la prensa obrera local y provincial. Fue relacionándose con círculos obreristas y específicamente anarquistas y, tras la huelga de 1913 en la comarca, fue despedido definitivamente de la Riotinto Company Limited. Abandonó Nerva y comenzó así un periplo vital y un nomadismo -con los habituales cambios de trabajo y domicilio- que le llevaría primero a Barcelona, donde asentaría con sus contactos su militancia anarquista. La trashumancia asociada a ella le trasladaría en los años de la Primera Guerra Mundial a Andalucía, donde participó activamente como agitador y propagandista ácrata y confederal en los años del llamado Trienio Bolchevique: orador en mítines, conferenciante, maestro de escuelas racionalistas, colaborador y fundador de periódicos y publicaciones anarquistas, escritor de folletos, etc., Noja se fue especializando en una actividad militante relacionada más específicamente con la propaganda y la labor cultural. En particular en el mundo periodístico, pero también en el pedagógico, actuando como maestro en Valencia o en localidades cercanas como Alginet, donde se refugió tras la persecución policial de la que eran objeto los militantes cenetistas en los años del pistolerismo, y donde ejerció como maestro hasta $1923^{2}$.

1. Una aproximación global a la vida y la obra de Noja ha sido desarrollada en Javier NAVARRO NAVARRO, "Las caras del militante. Higinio Noja Ruiz (1894-1972): cultura y acción en el movimiento libertario español”, en Marta GARCíA CARRIón y Sergio VALERO GóMEz (eds.), Tejer identidades. Socialización, cultura y política en la España contemporánea, Valencia, Tirant Lo Blanch, 2018, pp. 137165. En 1996, se recogieron en un libro parte de las memorias noveladas inéditas del autor referidas a su etapa como maestro en Alginet a principios de los años veinte, así como testimonios de antiguos alumnos de Noja, un listado de su obra y un estudio introductorio: Higinio NoJA RuIZ, La Armonía o la escuela en el campo (Alginet, 1923) Prefacio y presentación de Marianne ENCKELL y Vicente MARTí. Prólogo de Paco MADRID, Barcelona-Lausanne, Virus-CIRA, 1996. Una reseña biográfica de Noja, en Miguel ÍÑIGUEZ, Enciclopedia del anarquismo ibérico, Vitoria, Asociación Isaac Puente, 2018, tomo II, pp. 1.896-1.897. Sobre su pensamiento social y económico, Xavier PANIAGUA FUENTES, "Introducció a l’obra d'Higinio Noja Ruiz”, en El País Valencià: 1931-1939, Arguments, 1, L’Estel, Valencia, 1974, pp. 47-58, e ídem, La sociedad libertaria: agrarismo e industrialización en el anarquismo español, 19301939, Barcelona, Crítica, 1982, pp. 237-250. Referencias sobre su colaboración al inicio de la década de los veinte en la Editorial Renovación Proletaria dirigida por Aquilino Medina en Andalucía, y donde publicó sus primeros folletos en Alejandro Civantos URRUTIA, Leer en rojo. Auge y caída del libro obrero (1917-1931), Madrid, Fundación Anselmo Lorenzo, 2017, pp. 137, 147, 149-150, donde se califica a Noja de "proteico propagandista onubense” (p. 137). Para referencias en general sobre sus libros y folletos publicados, Ignacio C. SORIANO y Francisco MADRID, Antología documental del anarquismo español, VI.I. Bibliografía del anarquismo en España, 1868-1939. Enriquecida con notas y comentarios http://www.cedall.org/Documentacio/IHL/Antologia\%20Documental\%20del\%20Anarquismo\%20espano l_Bibliografia.pdf (10 ed., aumentada, mayo 2021).

2. Referencias a Noja RuIz durante el Trienio Bolchevique en Juan DíAz DEL MoRAL, Historia de las agitaciones campesinas andaluzas, Madrid, Alianza, 1984 ( $1^{\text {a }}$ de 1928), pp. 230, 235 y 270. Sobre la etapa de maestro en Alginet en general, el ya citado NoJA, La armonía. 
Desde entonces, y hasta 1933, residió en varios lugares: Tarragona, Barcelona, Andalucía o París, pero sobre todo en Palma de Mallorca, donde se acabaría asentando estos años y que sería escenario por cierto de la novela en la que nos centraremos aquí: Un puente sobre el abismo. Desempeñó diversos trabajos (por ejemplo, en un taller de fotografía o en la Editorial Espasa Calpe). Aunque participó al parecer en la reunión fundacional de la FAI en Valencia en $1927^{3}$, su vida militante más activa y propagandista se atemperó algo durante esos años de la dictadura de Primo de Rivera; no desde luego en lo que se refiere a sus colaboraciones en prensa (con un fondo más doctrinal y cultural, eso sí), a su labor como escritor de folletos y sobre todo a lo literario, que es lo que más nos interesa aquí.

Sería a partir de 1923 cuando Noja comenzó a publicar varias novelas sobre temas sociales, algunas de éxito en los medios obreristas, entre ellas: Los galeotes del amor (almas cautivas) (1923), Los sombríos (publicada en París en 1925), La que supo vivir su amor (1928), Como el caballo de Atila (1929) o Un puente sobre el abismo (1932). Estos títulos son tan solo una parte de una prolífica producción literaria paralela a la ensayística- centrada en el terreno de la novelística y el cuento. Esa fue una de las fuentes de su prestigio en el mundo obrerista y libertario. En un artículo de 1929, a raíz de la aparición de su última novela, La que supo vivir su amor, se señalaba en la revista Estudios:

La clase proletaria no ha dado todavía un novelista, un escritor que saque a la publicidad todas sus fatigas, todos sus sinsabores y sus inquietudes con los anhelos reivindicadores: es cierto que se han hecho y se hacen diferentes ensayos publicándose muchas novelas cortas con las cuales se vislumbran en algunos autores futuros novelistas de excelentes cualidades para abordar de lleno este género literario, pero hasta la fecha no ha salido el escritor que busque sus expansiones en este género, o sea en la novela grande [...]. Hace falta que aparezca el Gorky que trace la novela del pueblo, del pueblo sufrido, del que produce, puesto que Blasco Ibáñez dio su Catedral, su Bodega y su Intruso; Pio Baroja nos hizo esas otras novelas ideológicas indefinidas; Concha Espina con El metal de los muertos, y Ciges Aparicio trazaron en sus novelas las fatigas de los mineros, pintándonos su dolorosa vida de trabajo [...]. Higinio Noja es sin duda uno de los escritores jóvenes que tiene más aptitudes para la novela, y pudiera ser quien emprendiera la labor que más arriba indicábamos, pues sus andanzas de provincia a provincia, sus conocimientos, su temperamento y su exquisito modo de describir las cosas y el ambiente, lo hace ser un novelista de cuerpo entero [...] es el novelista que se espera surja a describir la vida del paria del trabajo, que a pesar de todas sus miserias busca elevarse de su nivel cultural que las clases directoras les regatea ${ }^{4}$.

Se hacía referencia en esta reseña a dos de las novelas publicadas anteriormente por Noja: Los galeotes del amor (almas cautivas) (1923) y Los sombríos (1925). La primera era una historia de amor entre dos seres libres, muy en la línea de los temas habituales de la colección La Novela Ideal, el proyecto de La Revista Blanca y la

3. Juan GÓMEZ CASAS, Historia de la FAI, Bilbao, Zero, 1977, pp. 128.

4 Emilio SANTOLARIA, “Siluetas. Higinio Noja Ruiz”, Estudios, no 71 (1929). Por su parte, Vladimiro MUÑOZ señala que NOJA RUIZ, "como escritor libertario, fue una de las mejores plumas de España” (Antología ácrata española, Barcelona, Grijalbo, 1974, p. 159). El también conocido militante anarquista Josep PEIRATS le califica asimismo de "novelista de mucha talla" ("Para una monografía de escritores anarquistas españoles”, Ruta, $2^{\circ}$ época, nº 7 (1972)). 
familia Urales, que por cierto empezaría su andadura dos años después ${ }^{5}$. Los sombríos reflejaba la vida en una comarca minera, como la de Riotinto que tan bien conocía el autor. Noja siempre quiso inscribirse en lo formal en la tradición de la novela realista española, pero concibiendo asimismo su literatura como medio de expresión y expansión del ideal y como textos de tesis donde se reflexionara sobre temas de interés y debate colectivos (la violencia, el pacifismo, la pena de muerte, las relaciones de pareja, la desigualdad social, la educación) a partir de personajes atravesados por esos conflictos, internamente y/o en su relación con los demás ${ }^{6}$.

Paralelamente a esta obra literaria, que continuaría en años posteriores, Noja intensificó asimismo su labor ensayística, muy prolífica. Esta comenzó con sus colaboraciones en la prensa libertaria y muy destacadamente en revistas de pensamiento o culturales del mundo ácrata, como Generación Consciente-Estudios -que se iniciaron en la década de los veinte y que mencionaremos a continuación-, y pronto a través también de folletos y libros. Noja fue desgranando así su producción doctrinal y de reflexión en torno a múltiples temas sociales y culturales: desde la sociología y la economía al feminismo, la sexualidad o el control de la natalidad, pasando por el arte, la literatura, etc., así como en aspectos centrales de la organización social y económica de la revolución y la futura sociedad libertarias, a lo largo de la década de los treinta. Durante los años republicanos, la figura de Noja Ruiz acabará destacando en el terreno doctrinal dentro de los medios libertarios, tal como lo estaba haciendo en lo literario. Sus artículos y folletos en torno a la crisis económica del capitalismo y la necesidad de su superación, así como sobre los fundamentos de la nueva sociedad posrevolucionaria le otorgaron difusión y prestigio en este ámbito ${ }^{7}$.

A ello ayudó el hecho de no ocupar cargos dentro de las organizaciones anarcosindicalistas, o el no identificarse particularmente dentro de la lucha de tendencias que vivió el mundo confederal-anarquista en esos años, al igual, por cierto, que ocurrió con Estudios. Revista Ecléctica. Su militancia se situaba en la FAI, pero nunca ocupó cargos ni participó en su vida orgánica, más allá de su aportación doctrinal y de reflexión, como cuando el Pleno de Regionales celebrado por la FAI en 1933 le designó como ponente de un informe (dentro de una comisión en la que también figuraban Eusebio Carbó, Isaac Puente y José María Martínez) sobre el concepto de comunismo libertario y los planes a seguir después de la revolución. Asimismo, su lectura de la obra de Besnard y Cornelissen, y sus contactos con Marín Civera, director de la revista Orto y próximo a Ángel Pestaña (con quien Civera compartiría la aventura del Partido Sindicalista), le hicieron otorgar una mayor valoración a la estructura

5. Marisa SiguÁn Boehmer, Literatura popular libertaria. Trece años de “La Novela Ideal”, Barcelona, Península, 1981; Brigitte MAGNIEN, Serge SALAÜN y Carlos SERRANO, "Le discours amoureux dans La Novela Ideal. Tristes topiques", en Le discours des groupes dominés: domaines ibérique et latinoaméricain, París, Publications de la Sorbonne Nouvelle, 1986, pp. 101-109; Brigitte MAGNIEN, "La Novela Ideal (1925-1938) à la conquête de la conscience publique... avec de l'amour et des idées”, en Marie-Claude CHAPUT y Julio PÉREZ SERRANO (coords.), De l'anarchisme aux courants alternatifs: XIXe-XXIe siècles, Nanterre, Publidix/ Université de Paris X Nanterre, 2009, pp. 381-394.

6. NoJA dedicó su novela Como el caballo de Atila (Valencia, Estudios, 1929-1930) al conocido escritor Ramón Pérez de Ayala, "cuyas obras tanto deleite me han proporcionado, dedico esta obrita, como homenaje de simpatía y admiración”.

7. PANIAGUA, “Introducció a l’obra” y La sociedad libertaria, pp. 237-250. 
sindical en el esquema postrevolucionario y en general mostrar más permeabilidad a la influencia de las tesis sindicalistas ${ }^{8}$.

Como ha subrayado Javier Paniagua, en su pensamiento social Noja defendía con un enfoque profundamente evolucionista- la necesidad de una nueva organización social a partir de la constatación de la crisis contemporánea del capitalismo y la incapacidad manifiesta de éste para servir adecuadamente a las necesidades humanas ${ }^{9}$. Era partidario de una socialización global y de la desaparición de la propiedad privada; ello conllevaría la igualdad efectiva al tiempo que el pleno desarrollo de las fuerzas productivas, en un proceso que no debía protagonizar el Estado, sino la colectividad en su conjunto (a través en concreto de fórmulas como el municipio libre o la federación local de sindicatos), garantizándose plenamente así la auténtica libertad individual. Todo ello iba revestido de un pedagogismo que constituye también un elemento central del pensamiento de Noja, tanto en lo teórico como en su práctica docente como maestro, actividad que desarrollaría de una u otra manera a lo largo de toda su vida, bien en escuelas municipales u obreras (siguiendo el ejemplo de los maestros racionalistas inspirados -siguiendo la tradición libertaria- en el modelo de la Escuela Moderna de Ferrer y Guardia), bien como profesor particular.

A partir de mediados de la década de los treinta, Noja se estableció definitivamente en Valencia, y también durante los años de la Guerra Civil. En palabras de Pere Solà, allí actuó como el "intelectual orgánico" del anarquismo valenciano ${ }^{10}$. No sabemos si hasta ese punto, pero lo cierto es que Noja formaría parte por ejemplo del Consejo de Economía constituido en esa ciudad. En este período se interesó especialmente por el fenómeno colectivizador y la dimensión económica del proceso revolucionario, analizando su trayectoria, posibilidades y obstáculos en distintos libros y folletos aparecidos en esos momentos. Por otro lado, participó en mítines y conferencias, presidió la Asociación de Amigos de México en Valencia (constituida en marzo de 1937) y continuó sus colaboraciones en forma de artículos en distintas publicaciones anarquistas. Cabe destacar en especial su protagonismo en muchas de las iniciativas de carácter cultural -grupos, publicaciones en forma de revistas y libros, actos públicos, etc.- desplegadas por los círculos cenetistas y anarquistas de Valencia, y fue uno de los principales animadores de la vida cultural libertaria en la ciudad durante la contienda ${ }^{11}$. Afiliado a la sección de Periodistas y Escritores del Sindicato de la Industria Gráfica de la CNT, fue director de varias publicaciones culturales libertarias, como es el caso de Libre-Studio (Revista de Acción Cultural al Servicio de la CNT) y Semáforo (portavoz del Comité Ejecutivo de Espectáculos Públicos de Valencia, UGTCNT). Desde ambas escribió, por ejemplo, sobre su concepción del teatro social en general y en la nueva coyuntura revolucionaria.

El final de la guerra y la victoria franquista supuso para Noja el ocaso de su vida pública. En primer lugar, e inmediatamente, con la prisión, desde su detención en el Puerto de Alicante el último día del conflicto y hasta que en enero de 1941 se le

8. Gómez Casas, Historia de la FAI, pp. 163-164; Xavier Paniagua Fuentes, Educación y economía en el sindicalismo de Marín Civera, Valencia, ICE, 1979.

9. PANIAGUA, “Introducció a l’obra” y La sociedad libertaria, pp. 237-250.

10 Pere SOLÀ i GUSSINYER, Educació i moviment llibertari a Catalunya (1901-1939), Barcelona, Edicions 62, p. 208.

11. Javier Navarro Navarro, A la revolución por la cultura. Prácticas culturales y sociabilidad libertarias en el País Valenciano (1931-1939), Valencia, Universitat de València, 2004, pp. 222-224. 
concedió la libertad condicional. Volvió a Valencia y allí residió hasta su muerte en 1972. Sobrevivió dando clases particulares, entre otros trabajos, y continuó -como había hecho siempre- escribiendo de manera prolífica, ahora textos que quedarían sin embargo inéditos. Durante el franquismo, el anonimato y la lucha por la supervivencia marcarían la vida de un maestro, pensador y escritor libertario bien conocido hasta 1939, y sobre cuya obra y recuerdo se depositaría a partir de entonces un grueso manto de silencio y olvido ${ }^{12}$.

\section{Noja, Estudios y el pacifismo}

Como apuntábamos, un hecho fundamental en la trayectoria y obra de Noja fue su vinculación a la revista cultural libertaria Estudios (Valencia, 1928-1937), incluso ya desde los tiempos en que esta cabecera recibía el nombre de Generación Consciente (antes de la censura impuesta por la dictadura de Primo de Rivera sobre las publicaciones anti-natalistas y que motivó el cambio de denominación), surgida en Alcoi en 1923. Desde aquellos años veinte hasta el final de la vida de la revista, Noja mantuvo su colaboración con ella. El resultado fueron numerosos artículos (casi 40 solo en Estudios) sobre una amplia variedad de temas próximos a la sensibilidad social y cultural obrerista-anarquista: economía, revolución social, educación, arte, literatura, feminismo, control de natalidad, reforma sexual, etc. A ello hay que añadir la publicación de algún poema y de un relato en la colección "La Novela Mensual de Estudios” (El pueblo de la Virgen Brava, n. 76, diciembre de 1929).

Por otro lado, sus comentarios y reseñas bibliográficos aparecieron en muchos números de la revista. De hecho, Noja fue el titular de su sección bibliográfica durante gran parte de la vida de la publicación. Asimismo, Estudios contaba con un activo servicio de publicación de libros y un amplio catálogo editorial, y diversos títulos de Noja aparecieron también allí, tanto novelas como ensayos. Así pues, la obra de Noja se vincularía siempre y muy estrechamente a Estudios. Fue uno de sus principales animadores e inspiradores intelectuales, y en la práctica su auténtico director literario, junto al también escritor y militante libertario Antonio García Birlán (Dionisyos), quien desempeñó asimismo en la publicación un papel similar al de Noja, y tal vez (por la frecuencia de sus colaboraciones y su ascendiente en los temas médicos y sexuales que caracterizaban a la revista) al médico anarquista alavés Isaac Puente. Según Hermoso Plaja, Noja compró los derechos editoriales de Estudios a su propietario, el militante cenetista Joaquín Juan Pastor, nada más iniciarse la Guerra Civil ${ }^{13}$.

Estudios. Revista Ecléctica, publicada mensualmente en Valencia hasta 1937 (y con un total de 165 números contando desde la aparición de Generación Consciente en 1923), era una revista cultural libertaria, cuyas páginas cubrían una amplia variedad de campos, desde la ciencia, medicina, salud y sexualidad hasta la literatura, pedagogía, arte, filosofía o historia, pasando por la sociología o economía y temas como el naturismo, feminismo, pacifismo, anticlericalismo, etc. Su objetivo declarado era la

12. NOJA, La armonía, pp. 115-119, y NAVARRO, “Las caras del militante”, pp. 156-158.

13. Ignacio Clemente SORIANo JimÉnEZ, “Hermoso Plaja y Carmen Paredes Sans. El anarquismo silencioso, 1889-1982”, tesis doctoral, Universidad de Salamanca, 2002, p. 559. Joaquín Juan Pastor ha sido acusado por algunas fuentes libertarias de enriquecerse con este exitoso proyecto editorial, la revista Estudios y su amplio catálogo de librería (Salvador CANO CARRILLO, "Hombres del Movimiento Libertario. Higinio Noja Ruiz”, Cénit (Toulouse), 201 (1972)). 
formación cultural y ética de las clases populares en un sentido global, lo que incluía desde la cultura general hasta el debate sobre aspectos relativos a la transformación revolucionaria de los hábitos y conductas de vida ya mencionados. Toda esta labor se complementaba con un muy activo servicio de distribución de libros y folletos sobre esta amplia variedad de temas y una editorial propia, que llegó a publicar más de 150 libros y folletos a lo largo de la trayectoria de Generación Consciente-Estudios. Tal vez el rasgo más distintivo de la publicación, y que lo hacía más reconocible entre su público, era su apuesta por la difusión de la teoría y la práctica del neomalthusianismo y la eugenesia entre los medios populares y obreros, así como el debate en torno a los distintos temas relacionados con la reforma sexual -como era conocida en la época- $y$, en segundo lugar, su defensa del naturismo y la medicina alternativa ${ }^{14}$.

Pero otra característica de la revista fue su postura combativa en contra de la guerra y el militarismo y a favor de la paz y el internacionalismo, temas clásicos por otra parte del discurso anarquista, también en España ${ }^{15}$. Ya desde sus primeros números -y desde la época de Generación Consciente-, la publicación situó esta cuestión como uno de sus temas de atención; como muestra, está por supuesto el elevado número de artículos dedicados a ella (más de 70 solo en Estudios), pero también su presencia en su catálogo de libros y folletos, como veremos. Se trataba de concienciar sobre la necesidad de la paz universal, revelando lo absurdo y la locura de la guerra. En realidad, esta aparece como la derivación más monstruosa de la manipulación de las mentes propia de la sociedad burguesa y el sistema capitalista, que recurre a los más bajos instintos humanos (el patriotismo) para expandirse o simplemente perpetuarse, y por tanto no había guerra justa. Efectivamente, entre sus causas figuraban, en opinión de la revista, los manejos económicos del capitalismo -en particular los ataques a las industrias y al comercio de armas, "vendedores de la muerte", eran constantes-, los nacionalismos y por último, la síntesis aberrante de ambos factores: el fascismo, concebido como la continuación del más abyecto espíritu militarista en la sociedad civil ${ }^{16}$.

Así, en el contexto concreto de aquellos años, asistimos en Estudios a una denuncia creciente de la hipocresía de las grandes potencias internacionales, que se armaban en previsión de una nueva guerra mientras por otro lado pretendían mantener la paz mediante la ficción de teatrales conferencias organizadas por la Sociedad de Naciones. Efectivamente, la percepción mayoritaria entre los colaboradores de la publicación era que se preparaba un nuevo conflicto -dibujado con tintes apocalípticos

14. Sobre Estudios, Fco. Javier NAVARRO NAVARRO, 'El paraíso de la razón’ La revista Estudios (19281937) y el mundo cultural anarquista, Valencia, Alfons el Magnànim, 1997. Su dimensión transnacional en Javier NAVARRO NAVARRO, "Reforma sexual, control de natalidad, naturismo y pacifismo. La cultura libertaria trasatlántica en las décadas de 1920 y 1930: Estudios. Revista Ecléctica (1928-1937) y su proyección y redes en América”, Historia y Política, 42 (2019), pp. 145-174, https://doi.org/10.18042/hp.42.06.

15. Entre otros, José Álvarez JunCo, La ideología política del anarquismo español (1868-1910), Madrid, Siglo XXI, 1991 (1º ed., 1976), pp. 247-279; Lily LITVAK, Musa libertaria. Arte, literatura y vida cultural del anarquismo español (1880-1913), Barcelona, Antoni Bosch, editor, 1981, pp. 42-45; Rafael NuÑEZ FlORENCIO, “Patria y ejército desde la ideología anarquista”, Hispania, LI/2, 178 (1991), pp. 589-643.

16. Entre otros artículos, F. R., "La barbarie organizada”, Estudios, no 124 (diciembre 1933); Jorge LANDSMANN, "Los vendedores de muerte” (n $n^{\circ} 134$, octubre 1934); Rudolf RoCKER, "Los preliminares de la última guerra” ( $\mathrm{n}^{\circ} 140$, abril 1935) y Robert DESNOS, “Mercaderes de la muerte. Sir Basil Zaharoff” ( ${ }^{\circ}$ 154, junio 1936). 
debido al avance imparable de las tecnologías de la destrucción-, como mostraba el aumento constante de los presupuestos militares. Como respuesta a ello, se defendía la lucha contra la guerra y por la paz en todos los ámbitos, por ejemplo mediante el boicot a la participación en los conflictos y la defensa de la objeción de conciencia (y del lema "No iré”), así como una educación global en pro de la paz. Esta era parte intrínseca de la lucha libertaria, al atacar de raíz la manifestación más monstruosa del autoritarismo (y del militarismo y el Estado), causa última de la violencia, junto con la desigualdad propia del sistema capitalista ${ }^{17}$.

Pero además de ser parte, junto con el internacionalismo, de la ideología ácrata, el pacifismo era también una actitud moral en general que podía ser compartida con otros sectores e individuos no anarquistas, en una campaña común. Así, en Estudios se reprodujeron artículos de autores, escritores y personalidades de todo el mundo en favor de la paz, como fue el caso de Albert Einstein, a cuyo prestigio como científico se unía su pacifismo militante, y de quien se publicaron varios artículos y declaraciones en ese sentido $^{18}$. Asimismo, en Estudios se dio cuenta de la existencia y actividad de organizaciones pacifistas internacionales surgidas en este período de entreguerras, a través de artículos sobre las mismas o noticias sobre sus iniciativas, como es el caso de los Hogares Libres Internacionales, o de asociaciones como la Liga de Refractarios de la Guerra o la Liga Internacional de Combatientes por la Paz.

Sin duda, en todo lo dicho hasta aquí el ejemplo de la Gran Guerra de 1914-1918 jugó un papel fundamental, convirtiéndose en un ejemplo recurrente de la locura bélica y de la memoria pacifista y antimilitarista internacional. Y así ocurrió también en Estudios, donde se la recordaba a menudo, y en particular su balance de víctimas y destrucción. Así se hacía por ejemplo en una sección habitual de la revista titulada “¡Abajo la guerra!”. En ella era frecuente reproducir testimonios de supervivientes de la guerra europea, así como obras literarias ambientadas en ella, que describían con dureza la barbarie de la lucha y la muerte en las trincheras. También se recogían en este apartado declaraciones antibélicas de escritores y pensadores del más variado signo. La nómina de autores cuyos textos aparecieron aquí resulta significativa y abarca desde autores del pacifismo del XIX hasta personalidades del momento, así como novelistas del período de entreguerras (y muchos de ellos antiguos combatientes) en boga por entonces: Octave Mirbeau, Edmundo de Amicis, Leonid Andreiev, Leon Tolstoi, George Duhamel, Anatole France, Max Deauville, Albert Einstein, Bertrand Russell, Thomas Mann, Romain Rolland, Henri Barbusse, Ludwig Renn, Rudolf Rocker, Max Nordau o José Ingenieros, entre otros.

En el apartado de "Bibliografía” de Estudios, donde se recogían reseñas y comentarios sobre novedades en libros, folletos y revistas, y cuya autoría correspondió -recordemos- en muchos números de la publicación a Higinio Noja Ruiz, aparecieron críticas sobre ensayos (libros o folletos) de temática antibelicista, antimilitarista o pacifista, como las obras del escritor rumano Eugen Relgis a las que haremos referencia más adelante, el folleto de Otto Lehmann, La Internacional Sangrienta de los Armamentos (versión española de la Editorial Cénit, 1929) o el libro del conocido

17. Gaston LEVAL, "El zafarrancho de la muerte”, Estudios, n 142 (junio de 1935). Precisamente en "No iré” ( $n^{\circ} 137$, enero 1935) se reproduce un capítulo del libro de Gaston LEVAL, El prófugo, al que después haremos referencia. Juan MonEYA PUYO, “¡Abajo la guerra! Paz” (n¹37, enero 1935).

18. Albert EINSTEIN, "Pacifismo militante”, Estudios, no 94 (junio 1931) y “Lo que yo creo”, nº 152 (abril 1936). 
anarquista francés Gaston Leval dedicado al tema, El mundo hacia el abismo, publicado por la propia Editorial Estudios (1934), entre otros ${ }^{19}$. Pero lo que más llama la atención es el peso que en esta sección tuvo la literatura y el espacio dedicado al comentario de conocidas novelas sobre la Gran Guerra. Ello ocurrió sobre todo en el período 19291933, y a partir del boom de las publicaciones de la editorial Cénit (y otras similares), con su colección "La novela de guerra”, especializada de alguna manera -entre otros temas- en la difusión de esta literatura, de las que Estudios se hizo eco, y alrededor del éxito internacional de Sin novedad en el frente, de Erich Maria Remarque, en 1929 (versión española publicada por la editorial España ese mismo año) ${ }^{20}$. Así, se comentaron en la sección de "Bibliografía", casi siempre positivamente, Los que teníamos doce años, de Ernst Glaeser, y Paz del mismo autor; la ya mencionada Sin Novedad en el frente, de Remarque, y Después, también de este escritor alemán; Cuatro de Infantería, de Ernst Johannsen; El Sargento Grisha, de Arnold Zweig; El fuego, de Henri Barbusse, y Hay novedad en el frente, de Helen Zenna Smith ${ }^{21}$. Además, se acogían muy favorablemente las novelas de un escritor social también muy popular en esos años en estos medios, el rumano Panait Istrati, aunque no centradas estrictamente en la Gran Guerra, pero sí con una clara orientación pacifista y progresista ${ }^{22}$.

Por otro lado, un análisis del amplio catálogo de distribución de libros y folletos de la revista -que sumaba a los de su propia editorial los de otras muchas casas hasta llegar, según se anunciaba de manera general en 1929, a más de 2.000 títulos- revela asimismo la presencia de un significativo número de ellos relacionados con esta temática antibélica, antimilitarista y pacifista ${ }^{23}$. En lo literario, las novelas mencionadas en el párrafo anterior -y publicadas en España por las editoriales Cénit, especialmente, España o Lux- también fueron vendidas y distribuidas por Estudios en su catálogo, a las que habría que añadir, por ejemplo, Entre dos frentes. Novela de Paz, de Amor y de Justicia. Memorias de Madame Smit, de Eduardo Granada C. (Lux, 1930).

Pero centrándonos en los títulos publicados directamente por la Editorial Estudios sobre esta temática esos años, encontramos sobre todo ensayos (libros y folletos). Hemos contabilizado alrededor de una decena de títulos. Dos títulos del escritor libertario rumano y creador del "humanitarismo" Eugen Relgis (Los principios humanitaristas y La Internacional Pacifista, ambos de 1932); el ya citado El mundo hacia el abismo de Leval; el folleto El militarismo y la guerra (1931?); La fabricación de armas de guerra, de Rudolf Rocker (1932), así como una recopilación de textos

19. También el libro Todos, ahora, contra la guerra, del escritor anarquista de Argentina Jacobo MAGUID, publicada por Ediciones Nervio de Buenos Aires (1935), conocida revista ácrata de ese país, muy similar en sus características a Estudios.

20. Sobre Cénit, en particular, véanse las obras de Gonzalo SANTONJA, entre ellas, La República de los libros. El nuevo libro popular de la II República, Barcelona, Anthropos, 1989, pp. 39-99. Recientemente también CivANTOS, Leer en rojo, pp. 230-251.

21. Véase la sección de "Bibliografía” de la revista en los números 75 (noviembre 1929), 77 (enero 1930), 78 (febrero 1930), 80 (abril 1930), 92 (abril 1931) y 96 (agosto 1931). También se comentó "La Guerra”, obra teatral de Eugenio Navas, publicada por Ediciones “Teatro Selecto”, de Buenos Aires, y de la que se afirmaba que no estaba bien escrita, pero que la salvaba "la idea” ("Bibliografía”, Estudios, 69, mayo 1929).

22. Los cardos del Baragán, una de las novelas más conocidas de Istrati, sería publicada también por la editorial Estudios.

23. NAVARRo, El paraíso, p. 220, y en general, para un análisis de esta "Biblioteca" de Estudios y sus características, véanse pp. 219-231. 
antibélicos aparecidos en la colección popular de libritos “Ayer, Hoy y Mañana”, que puso en marcha la editorial: La guerra (1933); otro del mismo corte en esa colección con el título Patriotismo y nacionalismo (1934), y el folleto clásico de Bakunin, El patriotismo, editado ya en 1938. Atención especial merece asimismo el libro del propio Higinio Noja Ruiz sobre la figura de Gandhi: Gandhi, animador de la India, aparecido en 1932.

La Editorial Estudios se centró sobre todo en ese ámbito de los ensayos más que en el literario, ya que de alguna manera, como vimos, lo esencial de la literatura antibélica europea más conocida había sido publicada en castellano por las otras editoriales españolas comerciales ya mencionadas. No obstante, Estudios editó en concreto una obra teatral: “¡Abajo la Guerra!”, drama social en tres actos, original de Helios (seudónimo del militante anarquista valenciano Vicente Sanchis Palacio), en 1936, y uno de los volúmenes de las memorias de Gaston Leval, El prófugo (1935), en el que el anarquista francés narra, entre otras cosas, su huida de Francia tras negarse a participar en la Gran Guerra. Pero sin duda la contribución más importante de Estudios en el ámbito de la literatura antibélica fue la publicación en 1932 de la novela de Higinio Noja Ruiz, Un puente sobre el abismo.

\title{
Un puente sobre el abismo
}

En su catálogo editorial aparecido de 1932, la Editorial Estudios publicitaba la nueva novela de uno de los colaboradores más habituales de su revista en estos términos:

\begin{abstract}
Ninguna de las muchas obras escritas acerca y después de la gran Guerra, puede compararse con esta exquisita novela que acaba de escribir Noja Ruiz. Porque todas las novelas llamadas de postguerra lo son por ex combatientes de uno u otro bando que en forma más o menos amena llevan a sus páginas la visión dolorosa y trágica de las horas vividas, de los sufrimientos padecidos, y, cuando más, un sentimiento de rebeldía puramente objetiva, que dejan en el ánimo del lector una impresión desoladora. Hacía falta, pues, la obra escrita por un espíritu selecto, que hable al corazón y a la conciencia del mundo; que ahondando en el campo experimental de las causas que hacen posibles estas horribles luchas fratricidas, señale normas éticas, profundamente humanas, oriente al lector hacia finalidades elevadas, hacia una moral superior de convivencia humana que haga imposible la repetición de la bestialidad guerrera que ensangrentó los campos de Europa durante cuatro largos años y extirpó lo más bello y valioso de la raza. Y todo esto lo consigue Noja Ruiz en su preciosa novela, con una amenidad pocas veces igualada, interesando al lector desde las primeras páginas en una narración que subyuga la atención con entusiasmo y con deleite insuperables.
\end{abstract}

Asimismo, la cubierta del libro estaba ilustrada por uno de los artistas que colaboraba frecuentemente con la revista, Manuel Monleón, que fue también cartelista durante la guerra. Las cubiertas de Monleón para los libros y folletos de la editorial y para los números de la revista Estudios -al igual que las de su otro artista habitual, Josep Renau- se caracterizaban por su colorido, aspecto llamativo y atrevidas composiciones y fotomontajes, y se convirtieron sin duda en uno de los elementos más atractivos en la revista y sus colecciones de libros y folletos. En este caso (Figura 1), bajo el título y el nombre del autor, encontramos una composición con el fondo de un gran sol naciente sobre el mar, elemento muy frecuente en estas ilustraciones de Monleón. A la derecha, una figura masculina desnuda, de aspecto clásico y aire prometeico, que acaba de romper las cadenas que lo mantenían preso y cuyos restos vemos todavía colgando de sus muñecas (otro motivo frecuente en esta iconografía), se yergue en lo alto de un acantilado o risco abierto que cuelga sobre el mar. Más allá, otro 
risco, y entre ambos un puente formado simplemente por libros (elemento también recurrente), que no llega hasta el otro extremo todavía, pero que intuimos podrá acabar completado. Abajo, sobre las aguas, restos de lo que parecen fusiles con bayonetas y algún libro. Como veremos, la alusión a una de las principales ideas de la novela es aquí clara: la educación antibélica y la cultura pacifista acabarán a la larga, aunque no lo han hecho todavía, con las guerras.

Figura 1: Cubierta de Un puente sobre el abismo

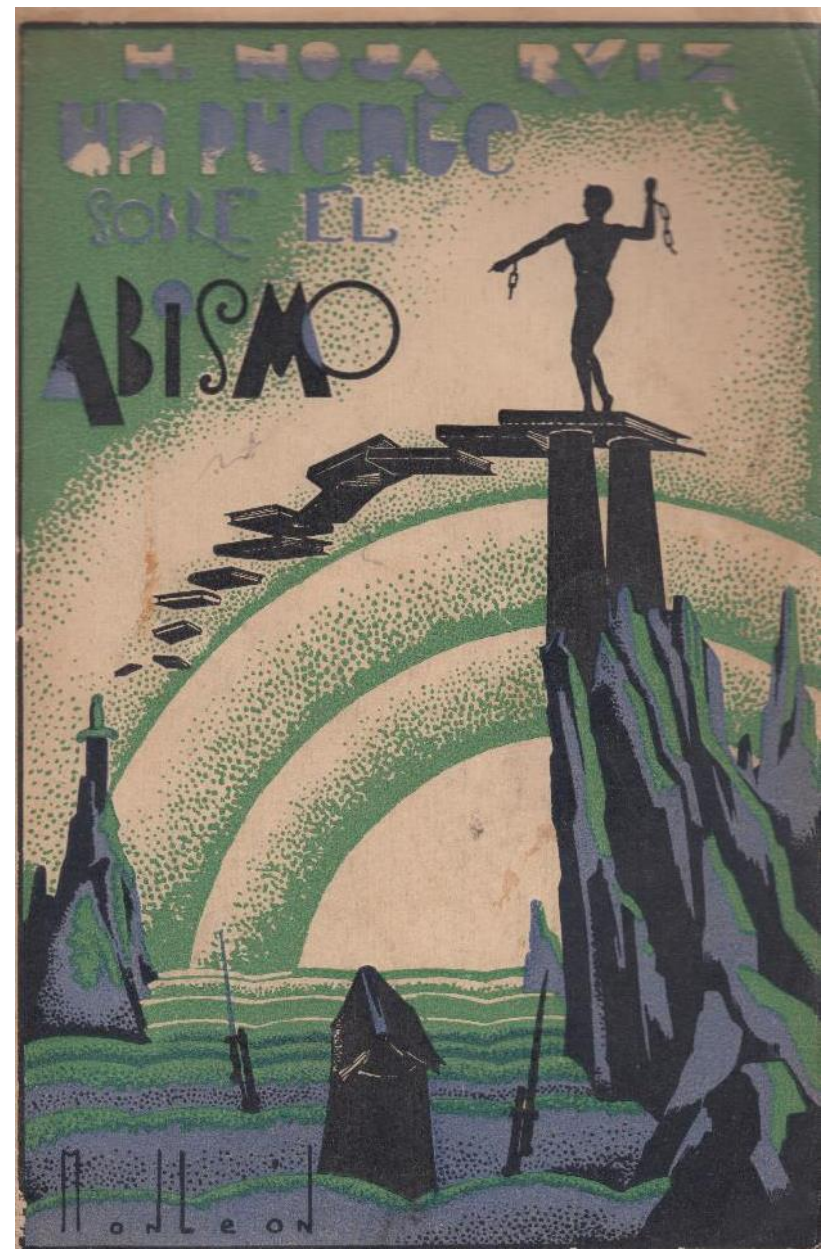

El protagonista de Un puente sobre el abismo es Guillermo Arjona, un burgués mallorquín contemporáneo al momento de escritura del relato. No nos encontramos aquí, por tanto, con un protagonista proletario, sino con un joven comerciante acomodado. Sobreexcitado por sus lecturas -fundamentalmente novelas, es decir, material literario- del conflicto y acosado por sus reflexiones e incluso las visiones del horror bélico que aquellas le provocan, Arjona va encontrar finalmente en la lucha contra las guerras y el compromiso con la pedagogía antibélica su razón de ser. También resulta significativo su origen familiar: un padre comerciante, hombre hecho a sí mismo, andaluz de nacimiento (como el propio Noja), de origen muy humilde y que labró su fortuna desempeñando todo tipo de oficios. Ello le llevó a viajar, a recorrer el mundo para ganarse la vida e imprimió en su carácter y pensamiento un espíritu cosmopolita y una vocación internacionalista:

Yo soy un ciudadano del mundo. En todas las latitudes he vivido y he sido amigo del hombre. La diferencia de idiomas y costumbres no me ha inducido a odiar a nadie. Ni el amor a mi tierra me ha arrastrado a mirar con encono a los que nacieron en otro suelo, del mismo modo que para amar a mi madre no me ha sido necesario odiar a las madres de los demás. Lo que separa a las personas no son las fronteras, sino el recelo que 
emana del mutuo desconocimiento. Conocerse y comprenderse es el método más seguro para acabar con los antagonismos de patrias y razas que son, en el fondo, una majadería ${ }^{24}$.

Arjona fue burgués progresista, algo librepensador, pero no amigo de revoluciones. Guillermo hereda ese espíritu nómada y el afán viajero de su padre. Sin embargo, Guillermo Arjona es al inicio de la novela un burgués de vida tranquila y previsible en su Mallorca natal. Será precisamente el efecto de esas lecturas antibélicas y su compromiso pacifista lo que obrará una transformación decisiva, como veremos, en el personaje. No obstante, también es un soñador, algo romántico e inquieto, que no se conforma -al menos en sus reflexiones- con lo que le ha reservado el destino. A la muerte de su padre, cuando contaba 18 años, tuvo que hacerse cargo del negocio familiar, pero esa ocupación no le satisface lo más mínimo. Carece de interés por lo empresarial o lo comercial. Le gusta dejarse llevar por sus ensoñaciones en sus paseos por Mallorca; le apasionan los paisajes y la historia de su tierra natal, pero también arde en deseos de ver mundo. Guillermo, sin embargo, aprovechó los años de la Gran Guerra para aumentar la fortuna familiar comprando y vendiendo. Y así, Arjona representa para Noja -pese a la diferencia social y a las distancias de todo tipo que separan a ambos caracteres, hay algo común entre Noja y Arjona más allá de la pista que proporciona la similitud de nombres- esa burguesía de los años del enriquecimiento rápido de tantos fabricantes y comerciantes de la España neutral durante la Primera Guerra Mundial; una burguesía que, por cierto, fue la que vio crecer a la CNT en medio del abismo de desigualdad social que se abrió en España en esos años. Algo hay en la novela de proceso de redención del personaje -aunque no se haga referencia explícita a ello-, por ese pasado en que se lucró beneficiándose de la masacre en los campos de Europa. Y, por tanto, algo también del poder redentor de las ideas que caracteriza el ethos libertario ${ }^{25}$.

La vida sentimental de Guillermo, sin embargo, no ha corrido pareja a su éxito en los negocios. Tras un desengaño amoroso, extrae de ello la lección de que la concepción romántica del amor es un fraude, y que conviene desenmascararlo de esas ficciones. Tan solo es real el "amor sexual" y la "pura fisiología, el contacto de dos epidermis”. Aquí aparece uno de los dos personajes femeninos de la novela. Es Margarita, la mantenida de Guillermo, quien recurre también en este caso a esa costumbre burguesa. Se trata de una joven campesina mallorquina a quien Guillermo conoció en un baile de máscaras. Tras iniciar una relación con ella, le proporcionó un piso y medios para una vida cómoda, con la aquiescencia de la familia de ella. Resulta interesante este personaje, que va adquiriendo mayor entidad a medida que avanza la novela y que va sorprendiendo a Guillermo (que no veía en ella más que a una joven simple y casquivana, sin cerebro) con sus maduras reflexiones en torno a su propia condición como mantenida y las causas sociales y económicas que la explican:

\footnotetext{
Debía pagar la honradez a un precio demasiado elevado y llegué a odiarla con toda mi alma y a desear deshacerme de ella cuanto antes. Entre la deshonestidad limpia y dorada y la decencia claudicante y fatigosa, durmiendo sobre basura, vistiendo cuatro andrajos y entreteniendo el hambre, preferí aquélla como la preferiría cualquier persona sensata. ¡Qué quieres! Los ditirambos a la honradez serán letra muerta mientras existan miserables. Solo se hallan en condiciones de ser honrados los ricos, y estos no necesitan
}

24. Higinio NoJA RUIZ, Un puente sobre el abismo. Narración, Valencia, Editorial Estudios, 1932, p.12.

25. Álvarez JunCo, La ideología, pp. 115-137. Arjona ama la paz y llega a decir que lo daría todo por la paz mundial: "Sin embargo, hubiera sacrificado su posición y su fortuna por instaurar sobre una base sólida, inconmovible, la paz del mundo” (NoJA, Un puente, p. 16). 
serlo [...]. Yo no tenía nada que vender en nuestro mundo de mercaderes y me vi precisada a hacer almoneda de mi belleza. Nada más lógico ${ }^{26}$.

Aunque al principio Guillermo la desprecia secretamente por haberse acomodado a un situación que él mismo ha preparado -lo que contradice incluso los propios principios que el protagonista dice mantener- ${ }^{27}$, el personaje de Margarita mostrará en sus opiniones una coherencia y una entidad moral finalmente superior a la del propio Guillermo:

\begin{abstract}
El amor es un sentimiento muy respetable y un bello motivo para componer novelas y poemas, mas yo no le podía dedicar ni el más leve espacio en mi alma. Lo que me preocupaba muy especialmente era salir de la miseria [...]. Mayor pecado es ser pobre. [...]. En una sociedad fundamentada en el poder del dinero, lo peor es carecer de él. Hay que apresurarse a conquistarle a toda costa, puesto que significa poder, bienestar, dicha, placeres. Por él vende el artista los frutos de su inspiración, el hombre de ciencia su talento, el obrero sus fuerzas, el militar su sangre. ¿Con qué derecho tildamos deshonroso que la mujer venda su belleza? [...]. A mi juicio, la sociedad que no se cuidó de asegurarme una existencia llevadera y digna en la honestidad, no tiene derecho a inmiscuirse en mis asuntos personales. Sin contar que el comercio sexual no tiene nada que ver con el honor ${ }^{28}$.
\end{abstract}

En realidad, las opiniones de Margarita, con su condena de la doble moral sexual burguesa, la denuncia de su hipocresía y con la argumentación sobre la motivación económica y social que explica su condición, vienen a reflejar la tradicional toma de postura del anarquismo español en torno la cuestión de la prostitución: exonerando a la prostituta de toda responsabilidad en una actividad absolutamente censurable, y considerando víctima a ésta de la explotación derivada de un orden social desigual y de aquella doble moral ${ }^{29}$. Este se convertirá en un subtema de la novela, a partir de las conversaciones entre Guillermo y Margarita, y finalmente, como veremos, con la despedida del primero al concluir el relato.

Otro personaje clave de la novela, también femenino, es Magda, la hermana de Guillermo, emancipada e independiente. Es una mujer libre, culta, compañera intelectual de su hermano, capaz de discutir con el sobre múltiples temas, entre ellos esa obsesión pacifista que constituye el tema central de Un puente sobre el abismo. Ha decidido no unirse a ningún hombre que "no la respetara enteramente y en todo momento y ocasión”. Quiere “mantenerse independiente, no obedecer más ley que su capricho, hacer lo que quisiera sin sujetarse a otros límites que los que a sí misma se impusiera", y por ello renuncia al matrimonio y a la maternidad, aunque en palabras de Noja, al renunciar a ello se condenara a ser "una mujer incompleta" ${ }^{30}$. Las conversaciones entre Guillermo y Magda serán nucleares en la novela, junto a las que el primero mantendrá con su compañero de tertulia, Pepe.

26. NoJA, Un puente, pp. 102-103.

27. “Comprobó en su trato íntimo con Margarita que ella conceptuaba aquello como el ejercicio de una profesión cualquiera, ni más ni menos deshonrosa que otras, y, en cambio, más cómoda y productiva [...] Le hubiera complacido que ésta hubiese fingido hallarse subyugada por el amor” (ibídem, p. 55).

28. Ibídem, pp. 104-106 y 149.

29. Álvarez Junco, La ideología, pp. 281-308; LiTVAK, Musa libertaria, pp. 80-93; Gérard Brey, "La prostitution dans la presse anarchiste espagnole (1881-1907)”, en Raphaël CARRASCO (ed.), La prostitution en Espagne. De l'époque des Rois Catholiques à la IIe République, Besançon, Centre de Recherches sur l’Espagne Moderne-Université Franche-Comté, 1994, pp. 345-357; NAVARRO, El paraíso, pp. 128-137.

30. NoJA, Un puente, pp. 26-27. 
Porque el perfil burgués de Guillermo se completa con otro de sus hábitos sociales: ser amigo de tertulias que suele compartir en un café con otros jóvenes. Aquí Noja completa las dramatis personce de esta novela y nos ofrece un cuadro vívido de esos compañeros de conversaciones y también a veces de excursiones por la isla: abanico variopinto de caracteres diversos, pero unidos todos ellos por su condición de jóvenes burgueses algo desocupados y ociosos, y de aire diletante. Entre ellos destaca Pepe, otro joven culto como Guillermo: individualista, polemista, y sobre todo antagonista y contrapunto de éste en sus largas discusiones -cumpliendo así sin duda un papel instrumental en la novela que permite el desarrollo de las argumentaciones-, pero en el fondo pasivo y conformista, como el resto de amigos (marcados por el tedio y la inercia), telón sobre el que destacará la decisión final de Guillermo de partir para Madrid y dar un nuevo rumbo a su vida.

Sin duda, la crítica a las guerras y sus estragos y la lucha antibélica son el tema principal de esta novela. Abundan aquí las reflexiones, a partir de los diálogos entre los personajes o de las meditaciones del protagonista, en torno a sus orígenes y causas, o sobre los medios para evitarlas. Estamos ante una novela fundamentalmente de ideas, en sintonía con una literatura social anarquista. Pero conviene resaltar que es asimismo un relato en que son frecuentes las descripciones de escenas y paisajes bélicos, ambientados en particular en el frente occidental durante la Primera Guerra Mundial. Son numerosos los fragmentos que reproducen, en un tono claramente apocalíptico, estos ambientes de trincheras, deuda evidente de la literatura sobre la Gran Guerra del período de entreguerras, y a la que la novela rinde sin duda un claro homenaje. Aparecen como visiones y ensoñaciones aterradoras del protagonista, que son frecuentes a lo largo de la novela. Herederas de las descripciones de esa literatura a menudo testimonial del conflicto, lo son también de sus representaciones visuales e incluso de la iconografía propagandística de la contienda. En una de las primeras visiones de Guillermo, sobre el paisaje nocturno de un campo desolado castigado por las bombas y el fondo de una ciudad incendiada y en ruinas se yergue un ser colosal y monstruoso, en realidad un enorme esqueleto tocado por un kepis, que porta en su cadavérica mano una bola del mundo en llamas -una representación de Marte, dios de la guerra, tal como se nos revela en la novela- y que nos recuerda muy claramente las composiciones de la cartelística de aquella guerra. Según el propio Guillermo, se trata de una visión apocalíptica de "lo que será la próxima guerra”, tal vez la definitiva.

Asimismo, y ocupando el espacio central de la novela y un capítulo entero de la misma, tenemos una sucesión de estas visiones y ensoñaciones del protagonista que se convierten en auténticos frescos descriptivos y narrativos de la Gran Guerra. El protagonista, agotado por sus cavilaciones y las discusiones sobre el tema en las que se enfrasca, descansa en su casa: no sabe si es un sueño o una ensoñación, pero Guillermo se convierte en espectador de cuatro escenas sucesivas que agitan su imaginación. La primera lo sitúa en agosto de 1914, al inicio del conflicto, en medio del entusiasmo de la movilización, en una ciudad francesa y en otra alemana. La segunda es ya un paisaje de trincheras presidido por las ametralladoras y los cañones; como en un desfile macabro, asistimos al despliegue de las peores armas de la guerra, concienzudamente mencionadas casi a título informativo para el lector: obuses, gas, tanques, etc. En la tercera escena, un bucólico pueblo enclavado en un verde valle es bombardeado y reducido a cenizas por la aviación; presenciamos también un combate aéreo en los cielos, seguido del ametrallamiento desde una escuadrilla a una columna de reclutas (como se cuenta, por cierto, en Sin novedad en el frente). En la última secuencia, nuestro protagonista se halla en una retaguardia castigada ya por el hambre y las 
privaciones de una larga guerra. Dos personajes sentados junto a él conversan: uno de ellos es el superviviente del hundimiento de un barco torpedeado por un submarino y que provocó que la mayor parte de su tripulación se ahogara en el mar; el otro es un espía.

El ascendiente de esa literatura sobre la Gran Guerra a la que aludíamos, tan en moda en la época y que Noja conocía bien, es evidente en la novela y no se esconde. Además de esas escenas aludidas de la guerra de trincheras, tan frecuentes en las alucinaciones y sueños de Guillermo, aparecen referencias explícitas a algunos de esos títulos, por cierto los mismos que, como veíamos, aparecían reseñados en la sección de "Bibliografía” de Estudios.

\begin{abstract}
Hacía meses que Guillermo venía entregándose con predilección al estudio de una literatura sugestiva, altamente interesante. Sobre la mesa de un despacho y en el momento de presentarle en escena, se veían distribuidos con cierto desorden "Sin novedad en el frente”, "Los que teníamos doce años”, "Cuatro de Infantería”, “Guerra”, "El sargento Grischa”, "El fuego en las trincheras”, y algunas estadísticas curiosas. Toda esta literatura bailoteaba en su cerebro una infernal zarabanda [...]. Aquellos libros reseñaban, cada uno en su tono, el resultado de aquel viento de locura que sopló en la vieja Europa durante cuatro años largos y que estremeció al mundo de uno a otro polo sembrando la desolación y el desconcierto en todas partes. La horrible sucesión de las espantosas escenas de barbarie evocadas por aquellos escritos, desfilaba impasible y tercamente ante los ojos de Guillermo, animadas a todo color, como algo vivo y palpitante $^{31}$.
\end{abstract}

Asimismo, en una de las reuniones con sus compañeros de tertulia, Guillermo comenta con ellos Sin novedad en el frente, de Remarque, auténtica sensación editorial del momento. La mayoría de ellos coinciden en que se trata de una interesante e intensa novela, aunque tanto Guillermo como Pepe subrayan que resulta menor en su potencial crítico respecto a la guerra de 1914-1918 que El Fuego, de Barbusse. Sin embargo, a diferencia de ésta, todos destacan que la novela de Remarque ha encontrado mejor momento en su aparición (1929) -once años después de la finalización de la guerra, y en un contexto en que el pacifismo parece cobrar cierto auge- que la de Barbusse, contemporánea al propio conflicto (1916).

Por otra parte, resulta interesante el espacio que Un puente sobre el abismo dedica a la discusión sobre la utilidad o no -en un sentido antibélico- de estas novelas, y en general del papel de la literatura para activar una toma de postura y un "cambio en las conciencias", en este caso en la condena de las guerras y la defensa de la paz. Este tema protagoniza varias conversaciones y debates en la novela -en los que participan significativamente sus personajes más importantes-, en primer lugar, la charla que sostienen Guillermo y Magda, su hermana, y que ocupa varias páginas. Guillermo trata de convencer a su hermana de la importancia de esta literatura antibélica, en la que Magda ve solo en principio curiosidad y morbo en sus lectores. Si para Guillermo, esta puede contribuir a la instauración de la paz, dado que "desnuda la conciencia humana”, muestra las causas y las consecuencias de la guerra, y por ello a la larga revela las contradicciones y errores de nuestra sociedad, para Magda, sin embargo, estos relatos conmueven, pero no enseñan. Para ella, profundamente pesimista, volverá a instalarse el sentimiento nacionalista y probélico en cuanto se presente de nuevo la ocasión. Guillermo, no obstante, se muestra a la vez la optimista y posibilista: el sentimiento de horror a la guerra que comunica estas novelas ya induce por ello a la reflexión y estimula de alguna manera el ánimo de evitarla. Significativamente, la conversación con

31. Ibídem, p. 19. 
Magda induce a Guillermo a profundizar en sus razonamientos. No se trata de quedarse en el rechazo de la guerra: hay que partir de esta condena, pero completarla con la apuesta por la reorganización de la sociedad. En todo caso, estas novelas constituyen un primer paso en la reflexión -como ha sucedido con el propio Guillermo-, al remover las conciencias, revelar la inutilidad de aquella enorme carnicería y mostrar los errores y carencias presentes en esta sociedad y la necesidad de su transformación.

Y aún más: el diálogo con Magda tiene su continuación en una conversación en torno al mismo tema que Guillermo tiene con sus compañeros de tertulia en el Café Alhambra, remarcando así el papel central de este debate en la novela de Noja. Para Pepe, partenaire habitual de Guillermo en sus discusiones y siempre incansablemente discrepante de sus opiniones, está literatura no tiene valor para evitar la guerra -“Creer lo contrario es excesivamente pueril. La guerra no puede evitarla la literatura”-, ya que esta se producirá de igual manera (preparar la paz... “¿editando libros?”). Para Pepe, la única literatura que puede tener éxito es aquella que proporcione "distracción y deleite, y no enseñanzas”. De una manera más general, en su argumentación Pepe se muestra como un darwinista social y así expone un punto de vista absolutamente contrario al de su amigo, y al anarquista en definitiva sobre la cuestión. La Naturaleza se encuentra siempre en permanente conflicto: nunca hay paz en ella, y en el ser humano los impulsos bélicos son también evidentes. Cree, sin embargo, que las cosas podrían cambiar, pero tras un "proceso educativo de siglos". Mientras tanto, "la gente leerá a Remarque, a Barbusse, a Renn y demás autores, pero no volverá la espalda al enemigo o al que como tal le señalen”. Para Pepe, los datos sobre el rearme de las principales potencias internacionales en esos años muestran que el pueblo será engañado de nuevo; se instrumentalizará otra vez el miedo, "un sentimiento más fuerte que el odio y que le arrastrará infaliblemente a una nueva conflagración”. No hay espacio para la esperanza: si al pueblo se le ordena de nuevo "uniformarse y empuñar el fusil, obedecerá sin chistar. Ha nacido y se le ha educado para eso"32.

El pesimismo escéptico de Pepe resulta un buen contrapunto al optimismo idealista de Guillermo y así se van sucediendo las argumentaciones sobre las causas y consecuencias de la Gran Guerra, y en general de los conflictos bélicos, en ocasiones muy prolijas. No es posible detenerse aquí en el análisis de todas ellas, pero sí en dos conclusiones a mi juicio fundamentales en este proceso de maduración de las reflexiones de Guillermo a partir de las conversaciones con Magda o Pepe, y que se observan a medida que transcurre la novela.

En primer lugar, la percepción de que, en el fondo, nos encontramos ante un problema colectivo, de origen social. La percepción de la brutalidad de la guerra fue para Guillermo el momento del despertar de su conciencia, pero no le pareció suficiente con el sentimiento antibelicista que despertó en él la lectura de esas novelas sobre la Gran Guerra. Por el contrario, un análisis racional le lleva a concluir que "todo se haya organizado para que la vida sea una cruel manifestación de la brutalidad ancestral, una cadena sin fin de cobardes asesinatos, un coro ensordecedor permanente de lamentos, gritos de triunfo y ladridos de odio”. De esa manera, la guerra del 14-18 se convierte en el catalizador que despierta esa conciencia social, la convicción de que "es preciso dar a la vida un sentido nuevo". Ese conflicto puso en evidencia la fragilidad de los valores morales de una sociedad y una civilización en declive. Es el momento de imprimir "un derrotero humano a la Vida, darle sentido, a concluir con su brutalidad”. Un sentimiento

32. Ibídem, pp. 41-50. 
humanitario, igualitario y fraterno, a través del cual el "hombre ha de hacerse hermano y aliado del hombre para apoderarse del planeta [...] y ser verdaderamente el rey absoluto de la Naturaleza”. Ello implica acabar con la división de la Humanidad en grupos tribales, en clases y castas, estableciendo la concordia y extirpando todo lo que sea elemento de rivalidad y enemistad. Para ello, "se necesita fundir todas las patrias existentes en una sola y hacer de la Humanidad una inmensa familia bien avenida”. Una llamada al sentimiento internacionalista de superación de las patrias, elemento discursivo claramente libertario ${ }^{33}$, como también lo es esa apelación a la Humanidad en su conjunto como destinataria de la lucha emancipatoria y no a una clase en concreto. Pero, ¿cómo? Ello solo será posible si se produce la desaparición de la desigualdad social: "Mientras la desigualdad económica nos agrupe en clases enemigas no es lógico esperar que esa necesaria concordia se establezca. Luego es preciso empezar por combatir para acabar con esa desigualdad, vivero de tantos males y eficiente principal de todas las guerras”34.

En realidad, el andamiaje social se sustenta en la fuerza y la guerra: "Es una necesidad vital del estado mantenerse armado y en pie de guerra". De nuevo encontramos aquí la argumentación discursiva anarquista: el origen de la guerra se sitúa en la doble perversión de la desigualdad social y el autoritarismo del Estado, que es el garante de ésta. Las soluciones reformistas no sirven mientras subsista esta desigualdad. La guerra, desde esta perspectiva, es un absurdo para los pueblos, ya que de ella se benefician muy pocos, a costa del empobrecimiento general. Acarrea la miseria. Por el contrario, la paz es el "principal elemento civilizador", "puesto que es en el seno de ella que se desenvuelven las artes, se perfecciona el hombre y se aumenta el patrimonio universal del progreso y de la cultura" 35 .

En segundo lugar, como hemos visto, la crítica y condena de las guerras no resulta suficiente por sí sola. También en línea con el discurso anarquista y la primacía en él de la acción, hay que actuar para evitar un nuevo conflicto, la posibilidad de otra guerra. Para conseguirlo, la única solución definitiva y efectiva es la demolición de la actual organización social y la llegada de una nueva época que contemple la transformación del orden social. Esa es en esencia la solución discursiva escogida en la novela y, como venimos diciendo, plenamente coherente con el pensamiento de su autor. Es la acción -y no meramente la reflexión o la capacidad dialéctica-, así como su decisión de trabajar efectivamente por la paz y el progreso social, lo que distinguirá más allá de sus palabras y opiniones- a Guillermo de la pasividad que encarna Pepe, profundo individualista y caracterizado por la lucidez de sus reflexiones, pero al mismo tiempo por el conformismo y la pasividad. De tal manera que, paradójicamente, la acción y la lucha para producir esa redención social son equiparadas a una guerra, pero a una guerra con sentido. Para Guillermo,

eso de la paz me suena falso. Vivimos en perpetua guerra, y, lo que es peor, en guerra estúpida. Yo me propongo dar sentido esa guerra y aferrarnos para que venga la verdadera paz y alcance en ella el individuo-hombre la plenitud de su desarrollo. Fácilmente se comprende que entre mi guerra y la que hasta el presente ha venido

33. ÁLVAREZ JunCO, La ideología, pp. 247-255.

34. NoJA, Un puente, pp. 121-123. Como apuntábamos, esta lucha no tiene por qué tener una definición o etiqueta ideológica precisa, ya que, en sintonía con un leitmotiv anarquista habitual, la lucha no es solo por la liberación de una clase, sino de la humanidad entera: “-¿Te sientes socialista? -No. Me siento hombr.”.

35. Ibídem, pp. 62-63. 
fraccionando el mundo, existe la misma diferencia que entre la efusión de sangre producida por el bisturí de un cirujano y la producida por el puñal del asesino. La una salva y la otra destruye ${ }^{36}$.

No obstante, y hay que subrayar esta idea, cabe entender necesariamente esta acción -igual que la totémica apelación a la acción directa en el anarquismo- de una manera amplia, polisémica. En ella cabe sin duda la labor formativa y cultural, o simplemente propagandística -considerada entre los libertarios como una siembra, tan importante como la lucha en las fábricas o las calles-, como la que caracterizaba la acción militante del propio Higinio Noja Ruiz ${ }^{37}$. Por otro lado, cuando en la novela Guillermo se interroga sobre el origen y causas de la Gran Guerra, ve el juego de los intereses económicos, de la industria armamentística y de la competencia capitalista en general por la conquista de los mercados. Pero se subraya asimismo aquí la importancia central que tuvieron las motivaciones ideológicas, y en particular el nacionalismo y el "patrioterismo" que se hallan en el origen de la "borrachera de entusiasmo" de 1914 y que nos habían devuelto en definitiva a la "bestia humana" y los instintos más primarios. Una locura colectiva que preparó el terreno para la carnicería y que fue posible gracias a la "propaganda envenenadora de las mentes" que había inoculado previamente el sentimiento patriótico y belicista en niños y jóvenes. Esta propaganda nacionalista, pensada para perpetuar el orden social, permitió que se viera en el prójimo al “enemigo natural” y que la guerra se produzca así “de manera lógica”38.

Dentro de esta labor propagandística, es significativo el espacio que Noja concede en su novela a la crítica de la prensa burguesa, reiterada una y otra vez. El autor que, como sabemos, intentó abrirse paso como periodista en Madrid entre 1919 y 1920 sin éxito y que conocía bien este mundo ${ }^{39}$, denuncia de manera vehemente cómo aquélla sembró el odio y así "todo lo que nos distancia de la bestia quedó ahogado":

En la prensa se propalaban noticias especiosas, se falseaban hechos, se desarrollaban campañas, con la mira puesta en caldear los ánimos y mantener a toda presión la atmósfera nociva de recelos y odios en todos los sectores de la sociedad, y en todos los rincones de la tierra ${ }^{40}$.

Así, por tanto, una tarea similar, pero en sentido contrario, es necesaria, y a ella decidirá finalmente Guillermo dedicar el resto de su vida. Se trata de un proyecto que va perfilando y que tiene una finalidad educativa y a largo plazo:

\section{Ibídem, pp. 138-139.}

37. Javier NAVARRo NAVARRO, "Los educadores del pueblo y la 'revolución interior'. La cultura anarquista en España”, en Julián CASANOva (coord.), Tierra y Libertad. Cien años de anarquismo en España, Barcelona, Crítica, 2010, pp. 191-217.

38. NOJA, Un puente, pp. 89-90.

39. Posteriormente ya se movería exclusivamente en el ámbito de la prensa obrera. Tras su paso por Madrid, NoJA partió en 1920 para Valencia, donde se integró en la redacción de Solidaridad Obrera, el diario portavoz de la CNT que, ante las dificultades por las que atravesaba la organización confederal en Barcelona, decidió trasladar a Valencia su publicación, bajo la dirección de Eusebio Carbó. La prensa burguesa recibe las críticas más contundentes y ácidas en la novela: “iEs un gran poder el de la Prensa! Poder educador dicen los farsantes y los imbéciles, pero en realidad no es más que una funesta embaucadora, una deshonesta damisela que sonríe a quien mejor le paga y está siempre dispuesta a defender las causas que no tienen defensa. En ella todo es superficial. Cultiva la mentira con verdadero amor" (ibídem, p. 49).

40. Ibídem, p. 84. 
La enseñanza en todos los grados. La prensa. La literatura. El cine... Sí, sí. Estos elementos eran los que habían de utilizarse para cimentar la paz, para desterrar per secula seculorum, el odioso espectro de la guerra. ¡Educación! Un concepto nuevo de la vida basado en la educación. [...] El hombre es hermano del hombre y debe ser ciudadano del mundo. Grabar esta verdad en el corazón humano será la inauguración de una era de paz tal vez inalterable y no puede grabarse sin dar un sentido nuevo a la enseñanza, hacer que la Prensa sea un verdadero vehículo de cultura, que el libro, el teatro y el cine, llenen una misión noble y educadora y que el hombre de ciencia trabaje para la vida ${ }^{41}$.

En la práctica, es un proyecto a la par educativo y propagandístico: "Pagaré, editaré y venderé a un precio mínimo, toda obra inspirada en tal sentido. Fundaré periódicos y revistas que respondan su contenido a lo que entiendo debe ser la Prensa. Procuraré que los maestros den a la enseñanza un valor de humanidad" ${ }^{42}$. En lo concreto, el plan de Guillermo tiene un contenido claramente editorial, ya que incluye un diario, una revista, una colección de novelas cortas y un catálogo de librería con “obras selectas” Un proyecto que recuerda extraordinariamente, por cierto, al de la propia revista y editorial de Estudios y que Guillermo plantea, no como un negocio, sino como una labor de difusión social y más aún, como "una especie de apostolado" 43 . Pero además de este despliegue editorial, el plan de Guillermo prevé la participación de pedagogos que orienten una obra educadora que tiene como fin "que el hombre vea con certeza cuáles son sus destinos y considere al hombre, sea cual fuere el pigmento de su pierna y el país en que haya nacido, como su hermano y aliado natural”, planteándose incluso la creación y sostenimiento económico de "algún centro de enseñanza inspirado en el nuevo programa”. También aquí la similitud con algunas revistas y empresas editoriales culturales libertarias del momento es clara, y muy específicamente con Estudios, de manera muy reveladora al referirse concretamente a recabar la colaboración de sociólogos y de “eugenistas competentes para exponer a la consideración del mundo, que en obras de valor destacado y permanente, todo lo relativo al problema de la eugenesia en su relación con el individuo y con la especie" ${ }^{44}$.

En definitiva, un proyecto ambicioso y de altos vuelos que Guillermo considera casi prometeico, ya que en esta vasta empresa "cabe todo lo que tienda a hacer del hombre un Dios, amo y señor de sus destinos, capaz y dispuesto a vivir su vida sin manchas en la vileza”. Es una tarea de concienciación que prevé a largo plazo, con el concurso de "muchas generaciones", una siembra para un futuro en que la humanidad destierre el recurso a la violencia: "Nuestros tiempos marcan el alborear de una época nueva: la de la lucha contra la violencia que ya no es necesaria como vehículo de progreso. En la actualidad se inicia un ciclo evolutivo durante el cual desaparecerá de las relaciones humanas toda idea de opresión y violencia”. Es una batalla que hay que emprender en un momento crítico entre dos épocas - "la época que muere y la época que nace"-, entre las que se abre un "abismo espantoso" y sobre el que Guillermo se plantea tender precisamente el puente que da título a la novela ${ }^{45}$.

Una entrega idealista, desinteresada, en la que Guillermo quiere invertir todos sus recursos y esfuerzos. Un "apostolado" que, muy significativamente, es criticado por

41. Ibídem, pp. 85-90.

42. Ibídem, p. 90.

43. Ibídem, pp. 119-120.

44. Ibídem, pp. 126-127.

45. Ibídem, pp. 92-93. En cursiva en el original. 
su hermana Magda. Ésta, aunque le promete su apoyo, ve en este plan de Guillermo no solo una empresa inútil y utópica, sino también un ejercicio diletante y narcisista:

solo te preocupas de ti mismo. No estás contento del rumbo que hasta ahora has seguido, te aburres y, por deporte, y también por vanidad, quieres asignarte el papel de redentor. Declaro sin ambages que eso me desagrada. Nunca me gustaron los redentores, pero me gustan infinitamente menos cuando lo son por egoísmo ${ }^{46}$.

Sin embargo, Guillermo no se ve mal en ese rol de apóstol, de modelo ético tan querido por la cultura libertaria ${ }^{47}$. "Había que luchar, que tornar al poeta en guerrero, que hacer del soñador un apóstol”, y acaba autopercibiéndose como un auténtico "guerrero pacifista" que quiere laborar por la paz y, por amor a ella, "encender y avivar una guerra gigantesca" 48 . Decide llevar adelante el proyecto mencionado pero, para ello, debe trasladarse a Madrid y dejar a Margarita. Esa aura de apostolado que Guillermo otorga a su plan le lleva a considerar un contrasentido "sostener a una hembra de placer", ahora que "planeaba un plan de campaña para la redención del mundo", revistiéndolo así de un componente puritano tan cercano a determinadas modulaciones de la ética y la cultura libertarias en España ${ }^{49}$. La respuesta de Margarita incide en esa coherencia moral y consideración positiva del personaje y su crítica a la doble moral sexual burguesa, como apuntábamos. Se ofrece a unirse al plan de Guillermo (“Trabajaremos juntos”), marchar con él a Madrid y ser su compañera. La respuesta de Guillermo, pese a desearlo también, es negativa ("No debo asociar a nadie a mi empresa. Y menos que nadie a ti”), y en ese momento éste reconoce sus propias contradicciones: "Él, que acariciaba el ensueño de la fraternidad universal, no poseía el suficiente valor moral para unirse a su querida a cara descubierta y hacerla madre" 50 .

Guillermo se despide finalmente de sus amigos en el puerto de Mallorca a punto de embarcarse hacia la Península y viajar a Madrid. Su hermana Magda lo acompañará más adelante, cuando él se instale en Madrid, y lo seguirá en su cruzada editorial. Pepe le reitera una vez más su escepticismo ante el éxito de esa misión, a la que califica de sueño destinado al fracaso. Mientras el barco enfila ya las aguas del Mediterráneo, Guillermo medita sobre ello:

¿Que no triunfaría? ¡Bah! ¡Qué más daba! Derrota y triunfo apenas si significan nada en el ánimo del luchador de abolengo. Avanzamos por la vida repartiendo y recibiendo mandobles. De esta lucha se deriva el progreso del hombre. Adelante. A los pies de la humanidad se ha abierto ella misma un profundo abismo. Es preciso salvarlo tendiendo sobre él un puente. En nuestra parte están el dolor, la barbarie y también la voluntad creadora. En la otra, en la opuesta, nos espera un futuro del que parten infinitas sendas que se orientan todas hacia el Superhombre ¡Hala! A pesar de los perezosos, de los escépticos y de los malintencionados, ¡manos a la obra! A tender un puente sobre el abismo $^{51}$.

Así pues, y en síntesis, asistimos a una maduración ideológica en el personaje que le conducirá al pacifismo -recordemos, desde la sensibilización antibélica que le

46. Ibídem, p. 92.

47. Javier NAVARRo NAVARRO, "El perfil moral del militante en el anarquismo español”, Spagna Contemporánea, 25 (2004), pp. 39-67.

48. NoJA, Un puente, p. 99.

49. Ibídem, pp. 95-96. Álvarez JunCO, 124-133; NAVARRO, “El perfil moral”, pp. 56-62.

50. NoJA, Un puente, p. 151.

51. Ibídem, p. 157. 
provocaron inicialmente esas novelas sobre la Gran Guerra-, y sobre todo a la convicción de que no se puede acabar con las guerras sin la transformación social global que acabe con la desigualdad, causa profunda, junto con el impulso autoritario, de aquéllas y de la violencia en general. Evidentemente, estamos ante una conclusión que se vincula con el pensamiento libertario del autor. Sin duda, el tema escogido por Noja enlaza con un tema de amplia tradición en el pensamiento radical y obrerista: el antibelicismo, antimilitarismo y pacifismo, con un importante peso en particular en la ideología y la cultura anarquistas, como vimos, y que resultaba muy familiar para los libertarios.

Otros elementos en la novela apuntan a esa orientación ideológica, y en particular a la visión de Noja del anarquismo. Es evidente, por ejemplo, el peso que tiene el elemento moral y la transformación personal del protagonista, que le lleva de un humanitarismo idealista a esa apuesta socialista/libertaria por el cambio social revolucionario. Recordemos por otro lado que el protagonista no es un héroe proletario, sino un burgués enriquecido de hecho durante la Gran Guerra, pero persona inquieta y fundamentalmente honesta que, a través de su búsqueda personal (como en todas las novelas de Higinio Noja Ruiz), experimentará a lo largo de la novela esa transformación moral que le decidirá por la acción, en este caso la tarea de despertar la movilización contra la guerras y el cambio social en lo que él mismo califica de una "especie de apostolado". También es significativo -y de clara inserción en el discurso anarquista- el peso que se otorga aquí a la educación y la formación en esa "revolución interior” y "de las conciencias" como elemento necesario en la emancipación social ${ }^{52}$, en particular en autores libertarios como Noja, partidarios de una concepción de la revolución tan culturalista, gradual y evolucionista.

No es casualidad tampoco que la campaña editorial, educativa y propagandística de carácter antibélico y pacifista que decide emprender al final el protagonista, y que planea convertir en su razón de ser y objetivo vital, sea en muchos puntos tan similar a la que protagonizaban en aquellos años revistas y editoriales culturales obreristas y, en este caso, específicamente libertarias. Revista, colecciones de libros y folletos a precios asequibles para su difusión popular, orientaciones pedagógicas y eugenistas... Como ya apuntamos, todo recuerda extraordinariamente el perfil de Estudios. Revista Ecléctica y su editorial, donde el antibelicismo y el pacifismo (junto con otros temas como la reforma sexual, el neomaltusianismo, la eugenesia, el naturismo o la medicina alternativa) se hallaron muy presentes, tanto en los números de la revista como en su catálogo de distribución de libros y folletos o en el de su propia editorial. Asimismo, y por las razones que también subrayamos anteriormente, la trayectoria de Noja Ruiz resulta absolutamente inseparable de esta: fuera en lo literario o en lo ensayístico, Noja y Estudios siempre estuvieron estrechamente vinculados.

Por otro lado, no es tampoco coincidencia que Noja ambientara su novela en una Mallorca en la que había estado residiendo varios años, que conocía bien y que sin embargo pronto abandonaría para trasladarse a Valencia. Otro homenaje, por tanto, que Noja decidió rendir aquí, en este caso a la isla y a sus paisajes. La Naturaleza de Mallorca es otro de los personajes de la novela y está siempre presente a lo largo de esta. También hay alusiones a la historia de la isla o a sus gentes, pero es sobre todo su Naturaleza la protagonista y Noja nos proporciona vívidas descripciones tanto de Palma y sus alrededores, como del mar, el campo y la montaña de la isla, como se relata en una

52. NAVARRO, “Los educadores del pueblo”, pp.191-196. 
excursión a Sóller. Hay una cierta exaltación aquí de la Naturaleza -tan frecuente por otro lado en el arte y la literatura anarquistas ${ }^{53}$-, que se erige a menudo en el telón de fondo que activa las reflexiones del protagonista. Más aún: ésta acaba por convertirse en una analogía del horizonte de liberación y redención social. Una "Mallorca universal", un paraíso de la Naturaleza a la vez que de la fraternidad humana ${ }^{54}$.

\section{Conclusiones}

En 1932 el escritor, ensayista y militante anarquista Higinio Noja Ruiz publicó la novela Un puente sobre el abismo en la Editorial Estudios de Valencia. En ella, Noja abordó el tema de las guerras y la lucha contra ellas, al igual que había hecho anteriormente con otras cuestiones sociales y culturales del momento que constituían también parte de sus preocupaciones y objeto de sus artículos en la prensa libertaria de aquellos años: las relaciones de pareja en Los galeotes del amor (almas cautivas); la situación social de una comarca minera en Los sombríos, o la pena de muerte desde el punto de vista de un verdugo (Como el caballo de Atila), por ejemplo. Estos temas sociales se encarnaban en novelas donde un/una protagonista solía experimentar un proceso de crecimiento (o caída), en conflicto interno y pugna paralela con un contexto que planteaba vivamente esas situaciones.

Como hemos visto, Noja Ruiz conocía buena parte de la literatura pacifista (sobre todo novelas) de aquellos años de entreguerras, literatura que había experimentado un cierto auge internacional de nuevo desde finales de la década de los veinte (alrededor en particular del éxito de Sin novedad en el frente, de Erich Maria Remarque en 1929). En España la editorial Cénit y otras dieron a conocer en español buena parte de esta novelística que se ambientaba en la Gran Guerra, fuera o no de carácter testimonial, con una voluntad más o menos crítica y caracterizada por mostrar vivamente la vida en las trincheras o la retaguardia, así como las consecuencias del conflicto. El propio Noja reseñó algunas de estas novelas -y también ensayos antimilitaristas o pacifistas- desde la sección de "Bibliografía” de Estudios, de la que fue titular durante buena parte de los números de la publicación, lo que prueba su lectura de las mismas, que en general solían recibir allí críticas bastante positivas. Es lógico, por tanto, que un Noja familiarizado con esta literatura y su éxito y difusión social esos años se planteara abordar la cuestión en una de sus novelas. Un puente sobre el abismo pudo funcionar así como un homenaje del autor a una literatura que sin duda le había influido, como prueban las referencias directas en la propia novela, o las escenas descritas en los sueños o visiones del protagonista (muy numerosos y presentes a lo largo del relato), claramente deudoras de aquella.

La novela aparece así por tanto casi como una especie de balance, dietario o libro de notas del propio Noja en torno a esa literatura. Es un ejercicio en buena medida metaliterario. Aparte de las referencias directas a esas novelas, o los pasajes ya mencionados, conviene recordar que varios diálogos y conversaciones entre personajes

54. Como también apunta LITVAK, la belleza del paisaje se puede convertir por tanto en una alegoría que aluda a la propia anarquía (ibídem, p. 26). "El genio del hombre puede transformar nuestro planeta en una Mallorca universal en la que se adunen por modo logrado la belleza una y varia de los paisajes, las dulzuras del ambiente y la jocunda alegría de vivir, pero antes es necesario limpiar de abrojos los caminos, purificar las almas de las macas del vicio y del rencor” (NoJA, Un puente, p. 100). 
presentes en Un puente giran en torno a ellas, se comentan sus características y, especialmente, su utilidad en la concienciación antibélica y pacifista (debate que ocupa varias páginas y distintos fragmentos de la novela). Asimismo, hay que recordar que es precisamente esa literatura la que ejerce un efecto catalizador sobre la conciencia del protagonista, la que le generará la inquietud (y el estado febril y casi alucinatorio en el que parece moverse sobre todo al inicio como consecuencia de estas lecturas) que le llevará a abandonar su vida de burgués conformista y sedentario y, tras un proceso de maduración personal, a la decisión de dedicarse por entero a la difusión del pacifismo, finalmente dentro de un plan general de transformación social muy próximo al ideario socialista-libertario.

Un puente sobre el abismo es una novela a menudo prolijamente discursiva, en la que abundan extensas discusiones y diálogos donde se exponen concienzudamente los distintos puntos de vista de los personajes, o amplias meditaciones y razonamientos del protagonista. Todo ello lastra sin duda lo narrativo. Asimismo, están presentes, por un lado, como apuntábamos, las descripciones y alusiones a los paisajes y lugares de Mallorca, así como - de manera muy significativa- pasajes que podríamos llamar alucinatorios, fragmentos que reproducen los sueños o visiones del personaje, a veces de carácter apocalíptico y que nos remiten a la imaginería bélica del conflicto de 19141918 y la guerra de trincheras, con presencia muy destacada de elementos procedentes de las descripciones literarias, periodísticas o artísticas de ésta.

Por las razones que hemos ido argumentando a lo largo de estas páginas, Un puente... constituye un buen ejemplo de la recepción, asimilación y reinterpretación de las novelas sobre el conflicto de 1914-1918 en los círculos obreristas españoles y específicamente libertarios, en este caso por parte de un escritor e intelectual perteneciente a ellos como Higinio Noja Ruiz, y también dentro de un proyecto editorial y cultural ácrata como es el caso de la revista-editorial Estudios. También de la opinión de estos medios sobre las guerras a la altura de inicios de la década de los treinta, dentro de un tema sobre el que tanto habían escrito y debatido los anarquistas y que constituía un eje temático de su discurso: el antibelicismo, el antimilitarismo y el pacifismo. Como vimos, Estudios desarrolló una activa campaña antibélica en varios frentes, y en ella la apelación al recuerdo de los desastres de la Gran Guerra fue habitual. Desde la revista se recibieron favorablemente estas novelas, así como los textos, declaraciones e iniciativas de escritores, intelectuales, pensadores y distintas personalidades a favor de la paz, o de organizaciones del pacifismo internacional. Poco a poco, a partir de 1933, con la llegada de los nazis al poder en Alemania y la agresiva política exterior de estos y de Mussolini, el fascismo fue personificando crecientemente esta amenaza militarista y bélica. En julio de 1936, el golpe militar en España y la guerra que desencadenó situaría a los anarquistas en un dilema -ante la necesidad de la lucha antifascista y la defensa de la República o la revolución- que pondría en debate y cuestión su clásico lema: realmente, ¿no había guerra justa? 